\title{
ANALISA SISTEM PENTANAHAN TRANSFORMATOR
}

\author{
Irine Kartika F
}

Program Studi Teknik Elektro Fakultas Teknik Universitas PGRI Palembang

e-mail : irenekf@univpgri-palembang.ac.id

\begin{abstract}
ABSTRAK Pentanahan adalah melakukan koneksi sirkuit atau peralatan ke bumi. Sistem pentanahan yang kurang baik dapat menyebabkan penurunan kualitas tenaga listrik. Ilmu pertanahan sering kali dianggap remeh, padahal pentanahan yang baik sangatlah penting. ketidakseimbangan beban menyebabkan arus tiap fasa pada Transformator daya \#3 60MVA 150/20 KV menjadi tidak seimbang yaitu IR $=\mathbf{9 5 4 , 3 7} \mathbf{A}, \quad \mathbf{I S}=\mathbf{9 6 8 , 3 2}$, IT = 950,24 A. Besarnya ketidak seimbangan beban (\%) antara tiap-tiap fasa pada Transformator daya \#3 60MVA 150/20 KV adalah $\mathbf{0 , 7 4 1 2} \%$, hal ini disebabkan karena penggunaan beban yang tidak merata. Sebagai akibat dari ketidakseimbangan beban antara tiap-tiap fasa pada Transformator daya \#3 60MVA 150/20 KV maka akan mengalir arus di netral transformator IN = $\mathbf{1 6 , 4 0 5 7 4} \angle-\mathbf{7 2}^{\circ} \mathbf{5 9}^{\circ}$. rugi-rugi daya akibat adanya arus netral adalah $\mathbf{0 , 7 0 7 3} \mathrm{W}$. tegangan titik netral terhadap tanah $\mathbf{- 2 2 , 3 2} \mathbf{V}$. arus netral yang mengalir ke tanah adalah $\mathbf{2 3 , 1 7 6 8} \mathrm{A}$. rugi-rugi daya akibat arus netral yang mengalir ke tanah adalah $\mathbf{1 , 4 1 1 6} \mathrm{W}$.Arus yang mengalir ketanah dari kedua transformator adalah 22,23699 Ampere. Tahanan pentanahan adalah $\mathbf{R}_{\mathbf{1}} \mathbf{0 , 0 6 9 2} \Omega$ dan $\mathbf{R}_{\mathbf{2}} \mathbf{0 , 1 8 5 6}$ $\mathbf{\Omega}$, sedangkan nilai tahanan pentanahan dengan cara parallel sebesar $\mathbf{1} \mathbf{\Omega}$, jadi salah Satu cara yang sangat efektif untuk menurunkan tahanan tanah adalah dengan memperdalam elektroda pentanahan.
\end{abstract}

Kata Kunci : Elektroda, Arus Netral, Sistem Pentanahan

ABSTRACT Grounding is connecting a circuit or equipment to the earth. Poor earthing systems can lead to decreased quality of electric power. Studies of land is often underestimated, but a good grounding is very important. While doing research in substations gutter oil, load imbalance on a substation Gutter oil, causing the flow of each phase at \# 3 60MVA power transformer 150/20 KVPT. PLN (Persero) substation Talang Kelapa Banyuasin become unbalanced that $\boldsymbol{I}_{R}=$ 954.37 A, $I_{S}=968.32, I_{T}=950.24 A$. The amount of load imbalance (\%) between each phase at \#

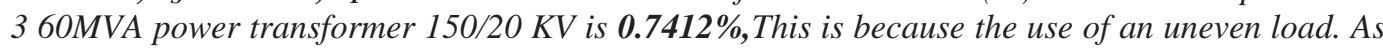
a result of load imbalance between each phase at \# $360 \mathrm{MVA}$ power transformer 150/20 $\mathrm{kV}$, the current will flow in the neutral transformer $\boldsymbol{I}_{N}=16,40574 \angle-72,59$. power loss due to the neutral current is $0.7073 \mathrm{~W}$. neutral point voltage to ground $-22.32 \mathrm{~V}$. neutral current flowing to ground is 23.1768 A. power loss due to neutral current flowing to ground is 1, 4116 W. current flowing to the ground from the second transformer is 22.23699 Ampere. Prisoners to the substation earthing gutter oil is $\boldsymbol{R}_{\mathbf{1}} \mathbf{0 , 0 6 9 2} \Omega$ and $\boldsymbol{R}_{\mathbf{2}} \mathbf{0 , 1 8 5 6} \Omega$, while the resistance value of the grounding in a way parallel $1 \Omega$, so either one very effective way to lose custody of land is to deepen the grounding electrode

Keywords: Electrodes, Current Neutral Grounding System

\section{PENDAHULUAN}

Kebutuhan daya listrik di Sumatera Selatan yang terus meningkat perlu diikuti dengan penyediaan daya listrik dengan cara menambah kapasitas transformator. Bertambah pesatnya jumlah penduduk juga mengakibatkan perlunya penambahan unit transformator baru. Sehingga terjadilah penambahan kapasitas transformator baru demi meningkatkan kestabilan sistem transfer tenaga daya listrik dari pembangkit ke konsumen.

Penambahan transformator baru membawa banyak manfaat. Beberapa manfaatnya antara lain memenuhi konsumsi energi listrik yang semakin besar kepada konsumen, untuk mengoptimalkan pembebanan transformator daya di Gardu Induk dan lain sebagainya. Oleh sebab itu, banyak Gardu Induk yang melakukan penambahan transformator baru, Sehingga di setiap Gardu Induk dibutuhkan sistem pentanahan,karena mengingat pentingnya pemahaman mengenai Sistem pentanahan Gardu Induk, sebab jika Sistem Pentanahan Gardu Induk tidak mengalami gangguan, maka pelayanan energi listrik kepada konsumen juga berjalan dengan optimal. 


\section{TINJAUAN PUSTAKA}

\section{Jenis Elektroda pentanahan}

Pada dasarnya ada 3 (tiga) jenis elektroda yang digunakan pada sistem pentanahan yaitu :

\section{Elektroda Batang}

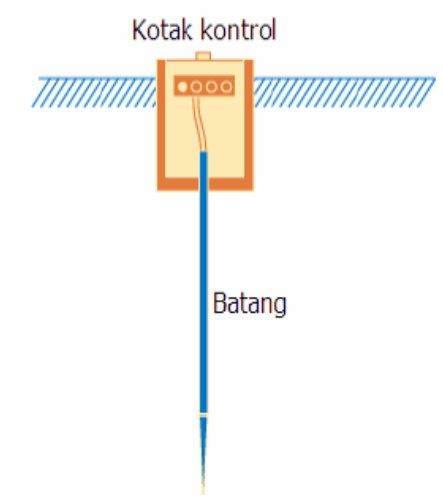

\section{Gambar Elektroda Batang}

https://www.kelistrikanku.com > Elektrikal

Elektroda batang yaitu elektroda dari pipa atau besi baja profil yang dipancangkan ke dalam tanah.Elektroda batang terbuat dari batang atau pipa logam yang di tanam vertikal di dalam tanah.Biasanya dibuat dari bahan tembaga, stainless steel atau galvanised steel. Perlu diperhatikan pula dalam pemilihan bahan agar terhindar dari galvanic couple yang dapat menyebabkan korosi

$\mathrm{R}_{\mathrm{bt}} 1=\frac{\rho}{2 \pi L}\left(\operatorname{Ln} \frac{4 L}{d}-1\right)$

Dimana :

Rbt 1 : Tahanan pembumian elektroda batang $(\Omega)$

$\mathrm{P} \quad$ : Tahanan jenis tanah $(\Omega \mathrm{m})$

$\mathrm{L} \quad$ : Panjang batang yang tertanam ( $\mathrm{m}$ )

d : Diameter elektroda batang ( $\mathrm{m}$ )

Ln : Logaritmus

\section{Elektroda Pelat}

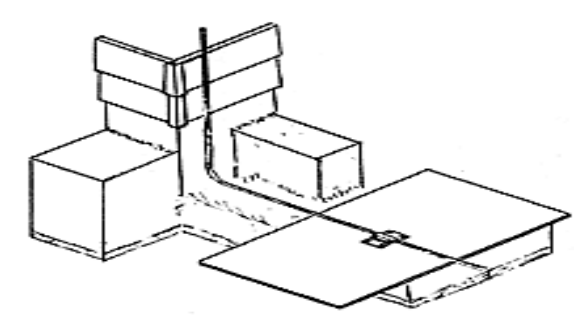

\section{Gambar Elektroda Pelat}

Bentuk elektroda pelat biasanya empat persegi atau empat persegi panjang yang tebuat dari tembaga, timah atau pelat baja yang ditanam didalam tanah.Cara penanaman biasanya secara vertical, sebab dengan menanam secara horizontal hasilnya tidak berbeda jauh dengan vertical.Penanaman secara vertical adalah lebih praktis dan ekonomis. 
$\mathrm{R}=\rho /(4,1 \mathrm{~L})(1+1,84 \mathrm{~b} / \mathrm{t})$

Dimana

$\mathrm{R}=$ Tahananentanahan pelat $(\mathrm{ohm})$

$\rho=$ Tahanan jenis tanah ( ohm-meter $)$

$\mathrm{L}=$ Panjang elektroda pelat ( meter)

$\mathrm{B}=$ Lebar pelat ( meter)

$\mathrm{T}=$ Kedalaman pelat tertanam dari permukaan tanah ( meter )

\section{Elektroda Pita}

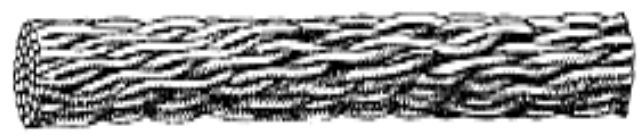

\section{Gambar Elektroda Pita}

Elektroda pita jenis ini terbuat dari bahan metal berbentuk pita atau juga kawat BCC yang di tanam di dalam tanah secara horizontal sedalam \pm 2 feet. Elektroda pita ini bisa dipasang pada struktur tanah yang mempunyai tahanan jenis rendah pada permukaan dan pada daerah yang tidak mengalami kekeringan. Hal ini cocok untuk daerah - daerah pegunungan dimana harga tahanan jenis tanah makin tinggi dengan kedalaman. Dan diadapat rumus tahanan pentanahan elektroda pita sebagai berikut:

$\mathrm{R}=\rho / 2 \pi \mathrm{L}[\ln$ (fo: $((4 \mathrm{~L}) / \mathrm{A})-1]$

Dimana

$\mathrm{R}=$ Tahanan pentanahan untuk batang tunggal ( ohm )

$\rho=$ Tahanan jenis tanah ( Ohm-meter )

$\mathrm{L}=$ Panjang elektroda ( meter )

$\mathrm{A}=$ Diameter elektroda ( meter $)$

Tabel 1. Tahanan Jenis Tanah dibawah Ini Menunjukkan Harga-Harga ( $\rho$ )

\begin{tabular}{|c|l|c|}
\hline No. & \multicolumn{1}{|c|}{ JENIS TANAH } & $\begin{array}{c}\text { TAHANAN JENIS TANAH } \\
\text { ( ohm.meter ) }\end{array}$ \\
\hline 1. & Tanah yang mengandung air garam & $5-6$ \\
2. & Rawa & 30 \\
3. & Tanah liat & 100 \\
4. & Pasir Basah & 200 \\
5. & Batu-batu kerikil basah & 500 \\
6. & Pasir dan batu krikil kering & 1000 \\
7. & Batu & 3000 \\
\hline
\end{tabular}

\section{Hal-Hal Yang Mempengaruhi Tahanan Tanah}

1. Panjang kedalaman elektroda pentanahan

2. Diameter Elektroda Pentanahan

3. Jumlah Elektroda Pentanahan 


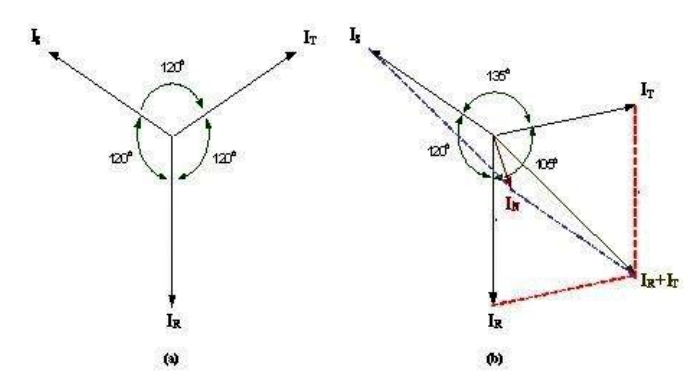

\section{Gambar vektor keadaan seimbang dan keadaan tidak seimbang}

Gambar (a) menunjukkan vektor diagram arus dalam keadaan seimbang. Di sini terlihat bahwa penjumlahan ketiga vektor arusnya (IR, IS , IT) adalah sama dengan nol sehingga tidak muncul arus netral (I). Sedangkan pada Gambar (b) menunjukkan Nvektor diagram arus yang tidak seimbang. Di sini terlihat bahwa penjumlahan ketiga vektor arusnya (IR, IS, IT ) tidak sama dengan nol sehingga muncul sebuah besaran yaitu arus netral (IN) yang besarnya bergantung dari seberapa besar faktor ketidakseimbangannya.

\section{METODOLOGI PENELITIAN}

Jika arus fasa dalam keadaan beban seimbang adalah sama dengan besarnya arus rata-rata:

$I_{\text {rata-rata }}=\frac{I_{R}+I_{S}+I_{T}}{3}$......

maka pada keadaan tidak seimbang besarnya arus-arus fasa dinyatakan dengan koefisien a, b dan c, yaitu:

$I_{R}=a \cdot I_{\text {rata-rata }}$ maka $a=\frac{I_{R}}{I_{\text {rata-rata }}}$.

$\mathrm{I}_{\mathrm{S}}=\mathrm{b} \cdot \mathrm{I}_{\text {rata-rata }}$ maka $\mathrm{b}=\frac{\mathrm{I}_{\mathrm{S}}}{\mathrm{I}_{\text {rata-rata }}}$

$\mathrm{I}_{\mathrm{T}}=\mathrm{c} . \mathrm{I}_{\text {rata-rata }}$ maka c $=\frac{\mathrm{I}_{\mathrm{T}}}{\mathrm{I}_{\text {rata-rata }}}$

Pada keadaan tidak seimbang, besarnya koefisien $\mathrm{a}, \mathrm{b}$, dan $\mathrm{c}$ adalah $\mathrm{a}+\mathrm{b}+\mathrm{c}=3$, sedangkan pada keadaan seimbang nilai koefisien $\mathrm{a}=\mathrm{b}=\mathrm{c}=1$. Kemudian besarnya arus rata-rata ketidakseimbangan beban dapat dinyatakan dalam persentase (\%), yaitu:

$I_{\text {ketidaksembanganbeban }}=\frac{\{|\mathrm{a}-1|+|\mathrm{b}-1|+|\mathrm{c}-1|\}}{3} \times 100 \%$

\section{Menentukan Arus Netral Karena Beban Tidak Seimbang}

Untuk arus tiga fasa dari suatu sistem yang tidak seimbang dapat juga diselesaikan dengan menggunakan metode komponen simetris. Dengan menggunakan notasi-notasi yang sama seperti pada tegangan akan didapatkan persamaan-persamaan untuk arus-arus fasanya sebagai berikut:

$\mathrm{I}_{\mathrm{R}}=\mathrm{I}_{1}+\mathrm{I}_{2}+\mathrm{I}_{0}$

$\mathrm{I}_{\mathrm{S}}=\mathrm{a}^{2} \mathrm{I}_{1}+\mathrm{aI} \mathrm{I}_{2}+\mathrm{I}_{0}$ 
$\mathrm{I}_{\mathrm{T}}=\mathrm{aI}_{1}+\mathrm{a}^{2} \mathrm{I}_{2}+\mathrm{I}_{0}$

Dengan tiga langkah yang telah dijabarkan dalam menentukan tegangan urutan positif, urutan negatif, dan urutan nol terdahulu, maka arus-arus urutan juga dapat ditentukan dengan cara yang sama, sehingga kita dapatkan juga :

$\mathrm{I}_{1}=1 / 3\left(\mathrm{I}_{\mathrm{R}}+\mathrm{aI}_{\mathrm{S}}+\mathrm{a}^{2} \mathrm{I}_{\mathrm{T}}\right)$

$\mathrm{I}_{2}=1 / 3\left(\mathrm{I}_{\mathrm{R}}+\mathrm{a}^{2} \mathrm{I}_{\mathrm{S}}+\mathrm{a} \mathrm{I}_{\mathrm{T}}\right)$

$\mathrm{I}_{0}=1 / 3\left(\mathrm{I}_{\mathrm{R}}+\mathrm{I}_{\mathrm{S}}+\mathrm{I}_{\mathrm{T}}\right)$

Di sini terlihat bahwa arus urutan nol $\left(\mathrm{I}_{0}\right)$ adalah merupakan sepertiga dari arus netral atau sebaliknya akan menjadi nol jika dalam sistem tiga fasa empat kawat. Dalam sistem tiga fasa empat kawat ini jumlah arus saluran sama dengan arus netral yang kembali lewat kawat netral, menjadi :

$\mathrm{I}_{\mathrm{N}}=\mathrm{I}_{\mathrm{R}}+\mathrm{I}_{\mathrm{S}}+\mathrm{I}_{\mathrm{T}}$

Dengan mensubstitusikan persamaan (11) ke (12) maka diperoleh:

$\mathrm{I}_{\mathrm{N}}=3 \mathrm{I}_{0}$

$\mathrm{I}_{\mathrm{N}}=\mathrm{I}_{\mathrm{R}}+\mathrm{I}_{\mathrm{S}}+\mathrm{I}_{\mathrm{T}}$

$\mathrm{I}_{\mathrm{N}}=[\mathrm{I}]\{\mathrm{a}+\mathrm{b} \cos (-120)+\mathrm{j} \mathrm{b} \sin (-120)+\mathrm{c} \cos (-120)+\mathrm{j} \mathrm{c} \sin (120)\}$

$\mathrm{I}_{\mathrm{N}}=[\mathrm{I}]\{\mathrm{a}+\mathrm{b}(-1 / 2)+\mathrm{j} b(-0,866)+\mathrm{c}(-1 / 2)+\mathrm{j} c(0,866)\}$

$\mathrm{I}_{\mathrm{N}}=[\mathrm{I}]\{\mathrm{a}-(\mathrm{b}+\mathrm{c}) / 2+\mathrm{j}(\mathrm{c}-\mathrm{b}) \sqrt{ } 3 / 2\}$

$\mathrm{I}_{\mathrm{N}}=\left[\mathrm{I}_{\text {rata-rata }}\right]\{\mathrm{a}-(\mathrm{b}+\mathrm{c}) / 2+\mathrm{j}(\mathrm{c}-\mathrm{b}) \sqrt{3} / 2\}$

Dalam sistem tiga fasa empat kawat ini jumlah arus dalam saluran sama dengan arus netral yang kembali lewat kawat netral. Jika arus-arus fasanya seimbang maka arus netralnya akan bernilai nol, tapi jika arus-arus fasanya tidak seimbang, maka akan ada arus yang mengalir di kawat netral sistem (arus netral akan mempunyai nilai dalam arti tidak nol).

\section{Menentukan Rugi-Rugi Daya Akibat Adanya Arus Netral}

Akibat pembebanan di tiap phasa yang tidak seimbang, maka akan mengalir arus pada penghantar netral. Jika di penghantar netral terdapat nilai tahanan dan dialiri arus, maka penghantar netral akan bertegangan yang menyebabkan tegangan pada transformator tidak seimbang. Arus yang mengalir di sepanjang kawat netral, akan menyebabkan rugirugi daya di sepanjang kawat netral sebesar:

$\Delta \mathrm{P}_{\mathrm{N}}=3 .\left(\mathrm{I}_{\mathrm{N}}\right)^{2} \mathrm{R}_{\mathrm{N}}$

Dimana:

$\Delta \mathrm{P}_{\mathrm{N}}=$ Rugi-rugi dayaakibat adanya arus netral (W)

$\mathrm{I}_{\mathrm{N}} \quad=$ Arus pada kawat netral (A)

$\mathrm{R}_{\mathrm{N}} \quad=$ Tahanan pada kawat netral $(\Omega)$ 


\section{Menentukan Rugi-Rugi Daya Akibat Arus Netral Yang Mengalir Ke Tanah}

Apabila arus akan mengalami gangguan tidak seimbang, sehingga akan berdampak pada pergeseran titik netral. Pergeseran terjadi tergantung pada besar kecilnya arus dari masing-masing fasa dan akan mengakibatkan terjadinya tegangan titik netral dengan titik pentanahan.Tegangan titik netral terhadap tanah dapat ditentukan dengan persamaan berikut:

Dimana :

$\mathrm{V}_{\mathrm{R}-\mathrm{N}} \quad=$ Tegangan fasa Rnetral $(\mathrm{V})$

$\mathrm{V}_{\mathrm{S}-\mathrm{N}} \quad=$ Tegangan fasa Snetral $(\mathrm{V})$

$\mathrm{V}_{\mathrm{T}-\mathrm{N}} \quad=$ Tegangan fasa Tnetral $(\mathrm{V})$

$\operatorname{Cos} \theta=$ Sudut antar fasa $\left(^{\circ}\right)$

$\mathrm{V}_{\mathrm{N}-\mathrm{G}}=$ Tegangan titik netral terhadap tanah $(\mathrm{V})$

Maka besarnya arus netral yang mengalir ke tanah dapat dihitung dengan menggunakan persamaan:

$$
I_{\mathrm{N}-\mathrm{G}}=\frac{\mathrm{V}_{\mathrm{N}-\mathrm{G}}}{\mathrm{R}_{\mathrm{N}-\mathrm{G}}}
$$

Dimana :

$\mathrm{I}_{\mathrm{N}-\mathrm{G}} \quad=$ Arus netral yang mengalir ke tanah (A)

$\mathrm{R}_{\mathrm{N}-\mathrm{G}}=$ Resistansi ke tanah dari sistem pentanahan $(\Omega)$

Rugi-rugi daya akibat arus netral yang mengalir ke tanah dapat dihitung dengan menggunakan persamaan:

$$
\Delta \mathrm{P}_{\mathrm{N}-\mathrm{G}}=\left(\mathrm{I}_{\mathrm{N}-\mathrm{G}}\right)^{2} \cdot \mathrm{R}_{\mathrm{N}-\mathrm{G}}
$$

Dimana:

$\Delta \mathrm{P}_{\mathrm{N}-\mathrm{G}}=$ Rugi-rugi dayaakibat adanya arus netral node ke $\mathrm{i}(\mathrm{W})$

Perhitungan Untuk satu batang elektroda ditanamkan tegak lurus digunakan rumus sebagai berikut :

$\mathrm{R}_{\mathrm{bt}} 1=\frac{\rho}{2 \pi L}\left(\operatorname{Ln} \frac{4 L}{d}-1\right)$

Dimana:

Rbt 1 = Tahanan pembumian elektroda batang $(\Omega)$

$\rho \quad=$ Tahanan jenis $\operatorname{tanah}(\Omega \mathrm{m})$

$\mathrm{L} \quad=$ Panjang batang yang ditanam $(\mathrm{m})$

$\mathrm{d} \quad=$ Diameter elektroda batang $(\mathrm{m})$

Ln = Logaritmus

\section{Perhitungan Beban Tidak Seimbang Transformator\#3}

Untuk mengetahui besarnya arus ketidakseimbangan beban ( $\mathrm{I}_{\text {ketidakseimbangan beban }}$ \%)Transformator daya \#3 60MVA 150/20 KV, terlebih dahulu mencari besarnya arus ratarata dengan menggunakan persamaan (13). Dari Tabel 2 diketahui bahwa $P_{R}=954,37 \mathrm{~A}$, 
$\mathrm{P}_{\mathrm{S}}=968,32 \mathrm{~A}$ dan $\mathrm{P}_{\mathrm{T}}=950,24 \mathrm{~A}$, maka arus rata-rata untuk Transformator daya \#3 60MVA 150/20 KV adalah:

$$
I_{\text {rata-rata }}=\frac{I_{R}+I_{S}+I_{T}}{3}=\frac{954,37+968,32+950,24}{3}=957,64 \mathrm{~A}
$$

Setelah didapatkan arus rata-rata, makadengan menggunakan persamaan (14), (15) dan (16)dapat ditentukan koefisien a, b dan c untuk Transformator daya \#3 60MVA 150/20 KVyaitu:

$$
\begin{aligned}
& \mathrm{a}=\frac{\mathrm{I}_{\mathrm{R}}}{\mathrm{I}_{\text {rata-rata }}}=\frac{954,37}{957,64}=0,9965 \\
& \mathrm{~b}=\frac{\mathrm{I}_{\mathrm{S}}}{\mathrm{I}_{\text {rata -rata }}}=\frac{968,32}{957,64}=1,0111 \\
& \mathrm{c}=\frac{\mathrm{I}_{\mathrm{T}}}{\mathrm{I}_{\text {rata-rata }}}=\frac{950,24}{957,64}=0,9922
\end{aligned}
$$

Kemudian dengan menggunakan persamaan (17)besarnya arus rata-rata ketidakseimbangan Transformator daya \#3 60MVA 150/20 KV dapat dinyatakan dalam persentase (\%), yaitu:

$$
\begin{aligned}
& I_{\text {ketidaksembanganbeban }}=\frac{\{|\mathrm{a}-1|+|\mathrm{b}-1|+|\mathrm{c}-1|\}}{3} \times 100 \% \\
& \mathrm{I}_{\text {ketidaksembanganbeban }}=\frac{\{|0,9965-1|+|1,0111-1|+|0,9922-1|\}}{3} \times 100 \% \\
& I_{\text {ketidakseimbanganbeban }}=0,7412 \%
\end{aligned}
$$

Dari hasil perhitungan tersebut ketidakseimbangan beban Transformator daya \#3 60MVA 150/20 KVadalah sebesar 0,7412 \%, hal ini disebabkan karena penggunaan beban yang tidak merata.

\section{Perhitungan Arus Netral Karena Beban Tidak Seimbang}

Dalam sistem tiga fasa yang arus fasanya tidak seimbang, maka akan ada arus yang mengalir di kawat netral sistem atau arus netral akan mempunyai nilai atau tidak sama dengan nol. Besarnya arus netral pada kondisi beban tidak seimbang dapat ditentukan dengan menggunakan persamaan (15), yaitu:

$$
\mathrm{I}_{\mathrm{N}}=\left[\mathrm{I}_{\text {rata-rata }}\right]\{\mathrm{a}-(\mathrm{b}+\mathrm{c}) / 2+\mathrm{j}(\mathrm{c}-\mathrm{b}) \sqrt{ } 3 / 2\}
$$

Dengan menggunakan persamaan tersebut dan menggunakan nilai koefisien $a, b$, dan $c$ maka arus netral Transformator daya \#3 60MVA 150/20 KVadalah:

$$
\begin{aligned}
& I_{N}=[957,6433]\{0,996582-(1,011149-0,992269) / 2+j(0,992269-1,011149) \sqrt{ } 3\} \\
& I_{N}=[957,6433,](0,996582-1,001709-j 0,0163505596) \\
& I_{N}=957,6433(0,005127-j 0,0163505596) \\
& I_{N}=\sqrt{(-4,9098371991)^{2}+(-15,6580038522)^{2}} \tan ^{-1} \frac{-15,6580038522}{-4,9098371991} \\
& I_{N}=16,40574 \angle-72,59^{\circ}
\end{aligned}
$$


Dari hasil perhitungan tersebut arus netral Transformator daya \#3 60MVA 150/20 KV adalah sebesar $16,40574 \angle-72,59^{\circ}$

\section{Perhitungan Rugi-Rugi Daya Akibat Adanya Arus Netral}

Akibat pembebanan di tiap fasa yang tidak seimbang, maka akan mengalir arus pada penghantar netral. Arus yang mengalir di sepanjang kawat netral, akan menyebabkan rugi daya di sepanjang kawat netral sebesar, maka rugi-rugi daya akibat adanya arus netral pada Transformator daya \#3 60MVA 150/20 KV dapat ditentukan dengan menggunakan persamaan (16), yaitu:

$$
\Delta \mathrm{P}_{\mathrm{N}}=\left(\mathrm{I}_{\mathrm{N}}\right)^{2} \cdot \mathrm{R}_{\mathrm{N}}
$$

Jika untuk penghantar netral Transformator daya \#3 60MVA 150/20 KV menggunakan jenis penghantar AAAC $70 \mathrm{~mm}^{2}$, dengan $\mathrm{R}=0,438 \Omega / \mathrm{km}$, dan $\mathrm{L}=0,006 \mathrm{Km}$, maka rugirugi daya akibat adanya arus netral pada Transformator daya \#3 60MVA 150/20 KV adalah:

$$
\Delta \mathrm{P}_{\mathrm{N}}=\left(\mathrm{I}_{\mathrm{N}}\right)^{2} \cdot \mathrm{R}_{\mathrm{N}}=(16,40574)^{2} \cdot 0,438 \cdot 0,006=0,7073 \mathrm{~W}
$$

Dari hasil perhitungan tersebut besarrugi-rugi daya yang disebabkan oleh adanya arus netral pada Transformator daya \#3 60MVA 150/20 KV adalah0,7073W.

\section{Perhitungan Rugi-Rugi Daya Akibat Arus Netral Yang Mengalir Ke Tanah}

Apabila arus akan mengalami gangguan tidak seimbang, sehingga akan berdampak pada pergeseran titik netral dan akan mengakibatkan terjadinya tegangan titik netral dengan titik pentanahan.Tegangan titik netral terhadap tanah dapat ditentukan dengan persamaan (17) dan (3.18), yaitu:

$$
\begin{aligned}
& \mathrm{V}_{\mathrm{R}-\mathrm{N}}+\mathrm{V}_{\mathrm{S}-\mathrm{N}}=\sqrt{\left(\mathrm{V}_{\mathrm{R}-\mathrm{N}}\right)^{2}+\left(\mathrm{V}_{\mathrm{S}-\mathrm{N}}\right)^{2}-2 \mathrm{~V}_{\mathrm{R}-\mathrm{N}} \mathrm{V}_{\mathrm{S}-\mathrm{N}} \operatorname{Cos} \theta} \\
& \mathrm{V}_{\mathrm{N}-\mathrm{G}}=\mathrm{V}_{\mathrm{T}-\mathrm{N}^{-}}\left(\mathrm{V}_{\mathrm{R}-\mathrm{N}}+\mathrm{V}_{\mathrm{S}-\mathrm{N}}\right)
\end{aligned}
$$

Dari data pada Tabel 1, diketahui bahwa $\mathrm{V}_{\mathrm{R}-\mathrm{N}}=11,801 \mathrm{~V}, \mathrm{~V}_{\mathrm{S}-\mathrm{N}}=11,847 \mathrm{~V}, \mathrm{~V}_{\mathrm{T}-\mathrm{N}}=11,766$ $\mathrm{V}$, maka tegangan titik netral terhadap tanah pada Transformator daya \#3 60MVA 150/20 KV adalah:

$$
\begin{aligned}
& \mathrm{V}_{\mathrm{R}-\mathrm{N}}+\mathrm{V}_{\mathrm{S}-\mathrm{N}}=\sqrt{(11801)^{2}+(11847)^{2}-2 \cdot(11801 \cdot 11847) \cdot \operatorname{Cos}-72,59^{\circ}} \\
& \begin{aligned}
& \mathrm{V}_{\mathrm{R}-\mathrm{N}}+\mathrm{V}_{\mathrm{S}-\mathrm{N}}=\sqrt{(139,263601)+(140,351409)-83,662228581554} \\
&=\sqrt{195,954103} \\
& \mathrm{~V}_{\mathrm{R}-\mathrm{N}}+\mathrm{V}_{\mathrm{S}-\mathrm{N}}= 13998 \mathrm{~V} \\
& \mathrm{~V}_{\mathrm{N}-\mathrm{G}}=11766-13998=-22,32 \mathrm{~V}
\end{aligned}
\end{aligned}
$$

Jika jenis kabel ground yang digunakan adalah AAAC $70 \mathrm{~mm}^{2}$, dengan $\mathrm{R}=0,438 \Omega / \mathrm{km}, \mathrm{L}$ $=0,006 \mathrm{Km}$ dan Ground rod $=0,002628 \Omega$, maka arus netral yang mengalir ke tanah pada Transformator daya \#3 60MVA 150/20 KVadalah:

$$
I_{N-G}=\frac{V_{N-G}}{R_{N-G}}=\frac{-22,32}{0,438 \cdot 0,006+0,9604}=-23,1768 \mathrm{~A}
$$


Rugi-rugi daya akibat arus netral yang mengalir ke tanah dapat dihitung dengan menggunakan persamaan:

$$
\Delta \mathrm{P}_{\mathrm{N}-\mathrm{G}}=\left(\mathrm{I}_{\mathrm{N}-\mathrm{G}}\right)^{2} \cdot \mathrm{R}_{\mathrm{N}-\mathrm{G}}
$$

Maka rugi-rugi daya akibat arus netral yang mengalir ke tanah pada Transformator daya \#3 60MVA 150/20 KVadalah:

$$
\Delta \mathrm{P}_{\mathrm{N}-\mathrm{G}}=(-23,1768)^{2} \cdot 0,002628=1,4116 \mathrm{~W}
$$

Dari hasil perhitungan tersebut besarrugi-rugi daya akibat arus netral yang mengalir ke tanah pada Transformator daya \#3 60MVA 150/20 KV adalah1,4116 W.

\section{Perhitungan Transformator\#1}

\section{Perhitungan Beban Tidak Seimbang}

Untuk mengetahui besarnya arus ketidakseimbangan beban ( $\mathrm{I}_{\text {ketidakseimbangan beban }}$ \%)Transformator daya \#1 60MVA 150/20 KV, terlebih dahulu mencari besarnya arus ratarata dengan menggunakan persamaan (13). Dari Tabel 2 diketahui bahwa $\mathrm{P}_{\mathrm{R}}=704,51 \mathrm{~A}$, $\mathrm{P}_{\mathrm{S}}=710,96 \mathrm{~A}$ dan $\mathrm{P}_{\mathrm{T}}=698,34 \mathrm{~A}$, maka arus rata-rata untuk Transformator daya \#3 60MVA 150/20 KV adalah:

$$
I_{\text {rata -rata }}=\frac{I_{R}+I_{S}+I_{T}}{3}=\frac{704,52+710,96+698,34}{3}=704,60 \mathrm{~A}
$$

Setelah didapatkan arus rata-rata, makadengan menggunakan persamaan (14), (15) dan (16)dapat ditentukan koefisien a, b dan c untuk Transformator daya \#1 60MVA 150/20 KVyaitu:

$$
\begin{aligned}
& \mathrm{a}=\frac{\mathrm{I}_{\mathrm{R}}}{\mathrm{I}_{\text {rata-rata }}}=\frac{704,52}{704,60}=0,9998 \\
& \mathrm{~b}=\frac{\mathrm{I}_{\mathrm{S}}}{\mathrm{I}_{\text {rata-rata }}}=\frac{710,96}{704,60}=1,0090 \\
& \mathrm{c}=\frac{\mathrm{I}_{\mathrm{T}}}{\mathrm{I}_{\text {rata-rata }}}=\frac{698,34}{704,60}=0,9911
\end{aligned}
$$

Kemudian dengan menggunakan persamaan (17)besarnya arus rata-rata ketidakseimbangan Transformator daya \#160MVA 150/20 KV dapat dinyatakan dalam persentase (\%), yaitu:

$$
\begin{aligned}
& \mathrm{I}_{\text {ketidaksembanganbeban }}=\frac{\{|\mathrm{a}-1|+|\mathrm{b}-1|+|\mathrm{c}-1|\}}{3} \times 100 \% \\
& \mathrm{I}_{\text {ketidaksembanganbeban }}=\frac{\{|0,9998-1|+|1,0090-1|+|0,9911-1|\}}{3} \times 100 \% \\
& I_{\text {ketidaksembanganbeban }}=0,6033 \%
\end{aligned}
$$

Dari hasil perhitungan tersebut ketidakseimbangan beban Transformator daya \#1 60MVA 150/20 KVadalah sebesar 0,6033 \%, hal ini disebabkan karena penggunaan beban yang tidak merata. 


\section{Perhitungan Arus Netral Karena Beban Tidak Seimbang}

Dalam sistem tiga fasa yang arus fasanya tidak seimbang, maka akan ada arus yang mengalir di kawat netral sistem atau arus netral akan mempunyai nilai atau tidak sama dengan nol. Besarnya arus netral pada kondisi beban tidak seimbang dapat ditentukan dengan menggunakan persamaan (15), yaitu:

$$
I_{N}=\left[I_{\text {rata-rata }}\right]\{a-(b+c) / 2+j(c-b) \sqrt{ } 3 / 2\}
$$

Dengan menggunakan persamaan tersebut dan menggunakan nilai koefisien a, b, dan c maka arus netral Transformator daya \#1 60MVA 150/20 KVadalah: $\mathrm{I}_{\mathrm{N}}=[704,60]\{0,9998-(1,0090+0,9911) / 2+\mathrm{j}(0,9911-1,0090) \sqrt{ } 3\}$

$I_{N}=[704,60](0,9998-1,00005-j 0,261587)$

$I_{N}=704,60(-0,00025-j 0,261587)$

$\mathrm{I}_{\mathrm{N}}=\sqrt{(-0,17615)^{2}+(-184,3142002)^{2}} \tan ^{-1} \frac{-184,3142002}{-0,176115}$

$\mathrm{I}_{\mathrm{N}}=5,83125 \angle-89,94^{\circ}$

Dari hasil perhitungan tersebut arus netral Transformator daya \#1 60MVA 150/20 KV adalah sebesar $5,83125 \angle-89,94^{\circ}$

\section{Perhitungan Rugi-Rugi Daya Akibat Adanya Arus Netral}

Akibat pembebanan di tiap fasa yang tidak seimbang, maka akan mengalir arus pada penghantar netral. Arus yang mengalir di sepanjang kawat netral, akan menyebabkan rugi daya di sepanjang kawat netral sebesar, makarugi-rugi daya akibat adanya arus netral pada Transformator daya \#1 60MVA 150/20 KV dapat ditentukan dengan menggunakan persamaan (16), yaitu:

$$
\Delta \mathrm{P}_{\mathrm{N}}=\left(\mathrm{I}_{\mathrm{N}}\right)^{2} \cdot \mathrm{R}_{\mathrm{N}}
$$

Jika untuk penghantar netral Transformator daya \#3 60MVA 150/20 KV menggunakan jenis penghantar AAAC $70 \mathrm{~mm}^{2}$, dengan $\mathrm{R}=0,438 \Omega / \mathrm{km}$, dan $\mathrm{L}=0,006 \mathrm{Km}$, maka rugirugi daya akibat adanya arus netral pada Transformator daya \#1 60MVA 150/20 KV adalah:

$$
\Delta \mathrm{P}_{\mathrm{N}}=\left(\mathrm{I}_{\mathrm{N}}\right)^{2} \cdot \mathrm{R}_{\mathrm{N}}=(5,83125)^{2} \cdot 0,438 \cdot 0,006=0,0893 \mathrm{~W}
$$

Dari hasil perhitungan tersebut besarrugi-rugi daya yang disebabkan oleh adanya arus netral pada Transformator daya \#1 60MVA 150/20 KV adalah0,7073W.

\section{Perhitungan Rugi-Rugi Daya Akibat Arus Netral Yang Mengalir Ke Tanah}

Apabila arus akan mengalami gangguan tidak seimbang, sehingga akan berdampak pada pergeseran titik netral dan akan mengakibatkan terjadinya tegangan titik netral dengan titik pentanahan.Tegangan titik netral terhadap tanah dapat ditentukan dengan persamaan (17) dan (18), yaitu:

$$
\mathrm{V}_{\mathrm{R}-\mathrm{N}}+\mathrm{V}_{\mathrm{S}-\mathrm{N}}=\sqrt{\left(\mathrm{V}_{\mathrm{R}-\mathrm{N}}\right)^{2}+\left(\mathrm{V}_{\mathrm{S}-\mathrm{N}}\right)^{2}-2 \mathrm{~V}_{\mathrm{R}-\mathrm{N}} \mathrm{V}_{\mathrm{S}-\mathrm{N}} \operatorname{Cos} \theta}
$$




$$
\mathrm{V}_{\mathrm{N}-\mathrm{G}}=\mathrm{V}_{\mathrm{T}-\mathrm{N}^{-}}\left(\mathrm{V}_{\mathrm{R}-\mathrm{N}}+\mathrm{V}_{\mathrm{S}-\mathrm{N}}\right)
$$

Dari data pada Tabel 1, diketahui bahwa $\mathrm{V}_{\mathrm{R}-\mathrm{N}}=11,655 \mathrm{~V}, \mathrm{~V}_{\mathrm{S}-\mathrm{N}}=11,676 \mathrm{~V}, \mathrm{~V}_{\mathrm{T}-\mathrm{N}}=11,640$ $\mathrm{V}$, maka tegangan titik netral terhadap tanah pada Transformator daya \#1 60MVA 150/20 KV adalah:

$$
\begin{aligned}
\mathrm{V}_{\mathrm{R}-\mathrm{N}}+\mathrm{V}_{\mathrm{S}-\mathrm{N}} & =\sqrt{(11801)^{2}+(11847)^{2}-2 \cdot(11801.11847) \cdot \operatorname{Cos}-72,59^{\circ}} \\
\mathrm{V}_{\mathrm{R}-\mathrm{N}}+\mathrm{V}_{\mathrm{S}-\mathrm{N}} & =\sqrt{(139,263601)+(140,351409)-25,148383} \\
& =\sqrt{15,952010} \\
\mathrm{~V}_{\mathrm{R}-\mathrm{N}}+\mathrm{V}_{\mathrm{S}-\mathrm{N}} & =3,9939 \mathrm{~V} \\
\mathrm{~V}_{\mathrm{N}-\mathrm{G}} & =11640-39939=-28,29 \mathrm{~V}
\end{aligned}
$$

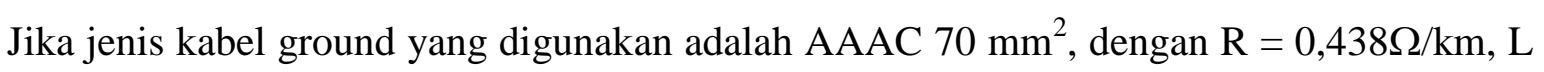
$=0,006 \mathrm{Km}$ dan Ground rod =0,002628 $\Omega$, maka arus netral yang mengalir ke tanah pada Transformator daya \#1 60MVA 150/20 KVadalah:

$$
I_{N-G}=\frac{V_{N-G}}{R_{N-G}}=\frac{-28,29}{0,438 \cdot 0,006+0,9604}=-29,3790 A
$$

Rugi-rugi daya akibat arus netral yang mengalir ke tanah dapat dihitung dengan menggunakan persamaan:

$$
\Delta \mathrm{P}_{\mathrm{N}-\mathrm{G}}=\left(\mathrm{I}_{\mathrm{N}-\mathrm{G}}\right)^{2} \cdot \mathrm{R}_{\mathrm{N}-\mathrm{G}}
$$

Maka rugi-rugi daya akibat arus netral yang mengalir ke tanah pada Transformator daya \#1 60MVA 150/20 KVadalah:

$$
\Delta \mathrm{P}_{\mathrm{N}-\mathrm{G}}=(-29,3790)^{2} \cdot 0,002628=2,2682 \mathrm{~W}
$$

Dari hasil perhitungan tersebut besarrugi-rugi daya akibat arus netral yang mengalir ke tanah pada Transformator daya \#1 60MVA 150/20 KV adalah2,2682 W.

Jadi, arus yang mengalir ke tanah dari kedua transformator tersebut dapat dihitung dengan menggunakan persamaan :

$$
\begin{aligned}
\mathrm{I}_{\mathrm{N}} & =\mathrm{I}_{\mathrm{N} 3}+\mathrm{I}_{\mathrm{N} 1} \\
& =16,40574+5,83125 \\
& =22,23699 \text { Ampere }
\end{aligned}
$$

\section{Perhitungan Perbedaan Tahanan Pentanahan Menggunakan Satu Batang Elektroda Pendek dan Panjang}

Pada bab ini akan dilakukan perhitungan penelitian tahanan pentanahan menggunakan metode satu batang elektroda pendek dan satu elektroda panjang pentanahan yang ditanamkan tegak lurus didalam tanah di sekitar transformator daya, dengan data-data yang didapat dari PT. PLN (persero) P3B Gardu Talang Kelapa Banyuasin, dalam hal ini tahanan spesifik jenis tanah tidak dilakukan pengukuran secara langsung jadi untuk menentukan besarnya tahanan jenis tanah ini dapat dilihat pada Tabel 1 tahanan jenis tanah Berikut data-data elektroda batang saat melakukan penelitian menggunakan Earth Resistance Tester. 
Tabel 3 Data Penelitian Elektroda Batang

\begin{tabular}{|l|l|l|}
\hline NO & Keterangan & Jenis / Ukuran \\
\hline 1. & Bentuk Elektroda & Batang \\
\hline 2. & Bahan Elektroda & Besi \\
\hline 3. & Panjang elektroda & $1 \mathrm{~m}$ \\
\hline 4. & Diameter Elektroda & $1,905 / 2=0,9525 \mathrm{~mm}$ \\
\hline 5. & Kedalaman Penanaman & $1 \mathrm{~m}$ \\
\hline 6. & Jenis Tanah & Tanah liat $=100$ ohm-meter \\
\hline
\end{tabular}

Untuk melakukan perhitungan tahanan pentanahan dengan menggunakan elektroda batang tunggal ini adalah dengan persamaan (8) yaitu :

$\mathrm{R}_{\mathrm{bt}} 1=\frac{\rho}{2 \pi L}\left(\ln \frac{4 L}{d}-1\right)$

Dimana :

Rbt 1 = Tahanan pembumian elektroda batang $(\Omega)$

$\rho \quad=$ Tahanan jenis tanah $=100 \Omega-\mathrm{m}$

$\mathrm{L} \quad=$ Panjang batang yang tertanam

$=1 \mathrm{~m}$

d $\quad=$ Diameter elektroda batang

$=1,905 \mathrm{~mm}$

$\mathrm{r} \quad=$ Jari-jari elektroda

$=1,905 / 2=0,9525$

Ln = Logaritmus

Dari persamaan diatas dapat diketahui bahwa besarnya resistansi pentanahan sangat dipengaruhi oleh jenis tanah, panjang elektroda, dan diameter elektroda. Berikut hasil perhitungan dari data pada tabel 3 :

1. Perhitungan menggunakan elektroda panjang 1 meter :

$$
\begin{aligned}
\mathrm{R}_{\mathrm{bt}} 1 & =\frac{\rho}{2 \pi L}\left(\ln \frac{4 L}{d}-1\right) \\
& =\frac{100}{2 \cdot 3,14 \cdot 1}\left(\ln \frac{4 \cdot 1}{0,9525}-1\right) \\
& =\frac{100}{628}\left(\ln \frac{4}{0,9525}-1\right) \\
& =0,1592 \times 0,4349 \\
& =0,0692 \Omega
\end{aligned}
$$

Jadi berdasarkan hasil perhitungan diatas nilai tahanan pentanahannya sebesar

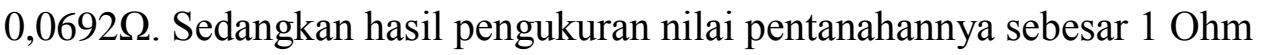

\section{Perhitungan menggunakan elektroda panjang 1,5 meter :}

$$
\begin{aligned}
\mathrm{R}_{\mathrm{bt}} 1 & =\frac{\rho}{2 \pi L}\left(\ln \frac{4 L}{d}-1\right) \\
& =\frac{100}{2-3,14 \cdot 1,5}\left(\ln \frac{4 \cdot 1,5}{12,7}-1\right) \\
& =\frac{100}{942}\left(\ln \frac{6}{12,7}-1\right) \\
& =0,1061^{*}-1,7498 \\
& =0,1856 \Omega
\end{aligned}
$$


Jadi nilai tahanan elektroda yang di pakai pada transformator sebesar $0,1856 \Omega$

Dari hasil perhitungan diatas didapat tahanan pentanahan adalah $R_{1} 0,0692 \Omega$ dan $R_{2}$ $0,1856 \Omega$, dapat dikatagorikan baik karena nilai tahanan pentanahan dibawah standar, tapi untuk mengurangi atau memperkecil lagi tahanan tersebut, maka dilakukan parallel dengan rumus dibawah ini :

$$
\begin{aligned}
\text { Rtotal } & =\frac{R_{1+R_{2}}}{R_{1+R_{2}}} \\
& =\frac{0,0692+0,1856}{0,0692+0,1856} \\
& =\frac{0,2548}{0,2548}=1 \Omega
\end{aligned}
$$

Jadi hasil perhitungan diatas nilai tahanan pentanahan dengan cara parallel sebesar $1 \Omega$ dan hasilnya sama dengan pengukuran menggunakan Earth Resistance Tester adalah $1 \Omega$

\section{KESIMPULAN}

Dari hasil perhitungan yang telah dilakukan pada sistem pentanahan transformator daya \#3 60MVA 150/20 KV maka dapat di ambil kesimpulan sebagai berikut :

1. Ketidakseimbangan beban pada Transformator 3 yaitu $\mathbf{I}_{\mathbf{R}}=\mathbf{9 5 4 , 3 7} \mathrm{A}, \mathbf{I}_{\mathbf{S}}=\mathbf{9 6 8 , 3 2}, \mathbf{I}_{\mathbf{T}}=$ 950,24 A. Besarnya ketidakseimbangan beban $(\%)$ antara tiap-tiap fasa adalah $\mathbf{0 , 7 4 1 2}$ $\%$, arus netral transformator $\mathbf{I}_{\mathbf{N}}=\mathbf{1 6 , 4 0 5 7 4} \angle \mathbf{- 7 2 , 5 9 ^ { \circ }}$. rugi-rugi daya akibat adanya arus netral adalah 0,7073 w. tegangan titik netral terhadap tanah $\mathbf{- 2 2 , 3 2} \mathbf{~ V}$. arus netral yang mengalir ke tanah adalah $\mathbf{2 3 , 1 7 6 8}$ A. rugi-rugi daya akibat arus netral yang mengalir ke tanah adalah $\mathbf{1 , 4 1 1 6}$

2. sedangkan Ketidakseimbangan beban pada Transformator 1 yaitu $\mathbf{I}_{\mathbf{R}}=\mathbf{7 0 4 , 5 1} \mathbf{A}, \mathbf{I}_{\mathbf{S}}=$ 710,96, $\mathbf{I}_{\mathbf{T}}=\mathbf{6 9 8 , 3 4}$ A. Besarnya ketidakseimbangan beban $(\%)$ antara tiap-tiap fasa

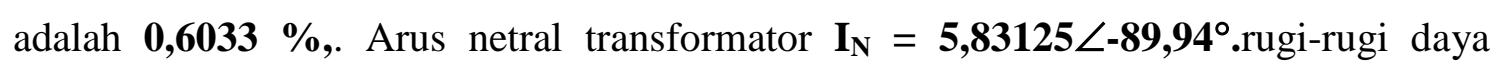
akibat adanya arus netral adalah 0,0893w. tegangan titik netral terhadap tanah $\mathbf{- 2 8 , 2 9} \mathbf{~ V}$. arus netral yang mengalir ke tanah adalah -29,3790 A. rugi-rugi daya akibat arus netral yang mengalir ke tanah adalah $\mathbf{2 , 2 6 8 2 ~ W}$

\section{DAFTAR PUSTAKA}

Hutauruk. 1987. Pentanahan Netral Sistem Tenaga \& Pentanahan Peralatan, Jakarta : Penerbit

\section{Erlangga}

MS Paraisu, F Lisi, LS Patras... - Jurnal Teknik Elektro ..., 2013 - ejournal.unsrat.ac.id https://www.kelistrikanku.com Elektrikal 